\title{
Multidimensional Aspect of Corporate Entrepreneurship in Family Business and SMEs: A Systematic Literature Review
}

\author{
Indra Wahyudi ${ }^{1}$, Arif Imam Suroso ${ }^{1, *(\mathbb{D})}$, Bustanul Arifin ${ }^{2}$, Rizal Syarief ${ }^{1}$ and Meika Syahbana Rusli ${ }^{3}$ \\ 1 School of Business, IPB University, Bogor 16680, Indonesia; Indrawahyudi@apps.ipb.ac.id (I.W.); \\ rizalsyarief@apps.ipb.ac.id (R.S.) \\ 2 Department of Agribusiness, Faculty of Agriculture, University of Lampung, \\ Bandar Lampung 35141, Indonesia; bustanul.arifin@fp.unila.ac.id \\ 3 Department of Agroindustrial Technology, Faculty of Agricultural Engineering and Technology, \\ IPB University, Bogor 16680, Indonesia; mrusli@apps.ipb.ac.id \\ * Correspondence: arifimamsuroso@apps.ipb.ac.id
}

Citation: Wahyudi, Indra, Arif Imam Suroso, Bustanul Arifin, Rizal Syarief, and Meika Syahbana Rusli. 2021. Multidimensional Aspect of Corporate Entrepreneurship in Family Business and SMEs: A Systematic Literature Review. Economies 9: 156. https://doi.org/ 10.3390/economies9040156

Academic Editors: João Carlos

Correia Leitão and Dina

Batista Pereira

Received: 24 September 2021

Accepted: 10 October 2021

Published: 20 October 202

Publisher's Note: MDPI stays neutral with regard to jurisdictional claims in published maps and institutional affiliations.

Copyright: (c) 2021 by the authors. Licensee MDPI, Basel, Switzerland. This article is an open access article distributed under the terms and conditions of the Creative Commons Attribution (CC BY) license (https:// creativecommons.org/licenses/by/ $4.0 /)$.
Abstract: This study aimed to review and analyze corporate entrepreneurship (CE) within family businesses and small and medium enterprises (SMEs), providing a review of the current state of research and suggesting a future research agenda. In a systematic literature review, 1040 articles indexed in Scopus were initially subjected to bibliometric and qualitative analysis. Finally, 53 papers published in various academic journals, focusing on corporate entrepreneurship, family businesses, and SMEs, were subjected to bibliometric analysis and qualitative research to identify the new potential state of the art in corporate entrepreneurship. CE in family businesses and SMEs is not a general research trend in the entrepreneurial area. This research shows that the literature on $\mathrm{CE}$ models and tools in family businesses and SMEs is still sparse. The review results correlate the actors of $\mathrm{CE}$, behavior, and activities, including entrepreneurial orientation, entrepreneurial management, and entrepreneurial leadership and performance, as outcomes in family business and SMEs.

Keywords: corporate entrepreneurship; family business; small and medium enterprise; structured literature review; bibliometric analysis; entrepreneurial orientation; firm performance

\section{Introduction}

Research on corporate entrepreneurship (CE) has been conducted with several methodological approaches and on multiple types of companies with varied samples. Some studies on CE are inconsistent, unclear, and present conflicting methodologies and findings (Schindehutte et al. 2018).

The definition of CE has been clarified by several previous researchers; in particular, $\mathrm{CE}$ focuses on the phenomenon and process of the birth of a new business within an old company utilizing innovation, or the creation of a new business and the transformation of the company through strategy renewal (Guth and Ginsberg 1990), with the aim of increasing the company's profits and overcoming the competition in the market (Zahra 1991). According to (Stopford and Baden-Fuller 1994), CE can be divided into three levels. The first involves individuals or groups that create new business within existing firms. The second is strategic renewal at the organizational level, and the third is competition in the industry with innovation. At the individual or group level, a team is adaptive, challenging, and can pursue entrepreneurial action (Schindehutte et al. 2018).

Based on research conducted by (Schindehutte et al. 2018), the CE phenomenon can be categorized using connections and boundaries, such as the determinant, protagonist, level of analysis, behavior, activities, and outcomes. The review in this study uses actors who are protagonists, variables consisting of behavior and activity, and outcomes as explained in Table 1. 
Table 1. Multidimensional connection in CE research.

\begin{tabular}{llll}
\hline \multirow{2}{*}{ Actor } & \multicolumn{2}{c}{ Variable } & Outcomes \\
\cline { 2 - 4 } & \multicolumn{1}{c}{ Behavior } & \multicolumn{1}{c}{ Activities } & \\
\hline Founder/CEO & Entrepreneurial orientation & Entrepreneurial leadership & Competitive advantage \\
TMT/Manager & Entrepreneurial management & Entrepreneurial venturing & New products \\
Employee & Entrepreneurial leadership & Entrepreneurial innovation & New ventures \\
Family & & & New markets/industries \\
& & & New business models \\
& & New strategies \\
& & Growth/survival \\
\hline
\end{tabular}

Source: Own understanding based on (Schindehutte et al. 2018).

A leader's critical character, value, and vision constitute entrepreneurial behavior within a company or organization (Guth and Ginsberg 1990). One of the activity variables associated with $\mathrm{CE}$ is the entrepreneurial orientation (EO), a process in entrepreneurship that has five dimensions: autonomy, innovativeness, risk taking, aggressive toward competitors, and a proactive approach to all opportunities (Lumpkin and Dess 1996).

Activity in CE takes three forms according to (Schindehutte et al. 2018), which are as follows:

Corporate venturing $(\mathrm{CV})$ consists of internal corporate venturing, external corporate venturing (ICV), corporate venture capital (CVC), and international venturing (INV).

The innovation process consists of developing new products, services, processes, and business model innovations.

The strategy formulation process consists of internal and external strategies for the sustainable regeneration and renewal of the company.

CE is essential for a family business for its long-term durability (Eddleston et al. 2012), and it is significant for the entrepreneurial spirit of an individual manager in exploring all opportunities and business ideas (Hornsby et al. 2009). Most researchers state that managers from family groups have high motivation to advance the company, and nonfamily managers are associated with two categories: motivation and behavior (Kotlar and Sieger 2019). The knowledge and expertise of a manager are not always available in family businesses because the family members or the owner will recruit several managers from outside as talent (Gedajlovic et al. 2004). Research on CE in family businesses involves both internal and external managers or top management teams (TMT).

Family firms can be divided into three elements, i.e., ownership, control, and management, which can have positive or negative consequences for the company (Villalonga and Amit 2006). In terms of ownership, this may be direct for a shareholder of a company or both direct and indirect control for the appointed management of a company or a board of directors (Gonzalez et al. 2019). The director, chairman, or CEO is the highest-ranking leader in the company, and their title depends on the level of the company and the size of the company. Family companies or SMEs are usually led by a director from the family or from outside.

On the national level, in general, the companies that are the backbone of the national economy are SMEs (Najmulmunir 2020). Research on CE in SMEs discusses many variables that influence CE. These include management support, reward/reinforcement, work discretion, time availability, and organization boundaries, which are usually defined using CEAI measurements (Hornsby et al. 2013). The review in this study will be carried out on companies classified as family businesses and SMEs, because previous research on CE was mainly carried out only on large companies or corporations. 
The literature has long recognized small and medium enterprises (SMEs) as fundamental to the world economy, and they play significant roles in growth, employment, and wealth creation (Roux and Bengesi 2014; Kiwia et al. 2020). Most of the SMEs throughout the world are family businesses (Poza and Daugherty 2014; Hnátek 2015). Combinations of family businesses and SMEs in certain areas are called family-owned SMEs (Kiwia et al. 2020). Family businesses and SMEs are critical components of entrepreneurship and are responsible for many contributions to the economic development of a country.

A few scholars have performed literature reviews focusing on CE; for example, the review of (Nadkarni and Prügl 2021) focused on a particular segment, the digital transformation industry, and (Weiss and Kanbach 2021) explored an integrated framework of corporate venturing for organizational ambidexterity as a dynamic capability. Other scholars (Mehta 2020) examined the effect of different leadership styles on CE and its components, and (Burger and Blažková 2020) identified internal determinants promoting $\mathrm{CE}$ in established organizations. Based on these literature reviews, and to the best of our knowledge, no SLR exists with reference to CE in family businesses and SMEs. This motivated us to conduct further research on SLR. According to (Massaro et al. 2016), SLR represents the beginning of a new research trend.

CE research in family businesses or SMEs is sparse in Scopus-indexed journals. In this study, a thorough discussion is presented that touches on actors, variables consisting of behaviors and activities, and outcomes in the form of financial and non-financial performance. This research aims to provide a comprehensive picture of the influence of the actors in the company by motivating each variable to achieve a particular kind of performance. We consider several research questions (RQ), which are as follows:

RQ1. Which variables are used to measure the multidimensionality of CE in family businesses and SMEs?

RQ 2. What is the focus of the methodology and theory within $C E$ for family businesses and SMEs regarding multidimensionality?

RQ 3. How is the literature on CE in family businesses and SMEs developing?

RQ 4. What are the theories used to explain CE in family businesses and SMEs?

Based on this literature review, the manuscript aims to provide new knowledge of $\mathrm{CE}$ and its variables that can be used as a reference for future research. The main value of this review lies in the fact that it considers various types of $C E$ research from several disciplines, such as management, finance, accounting, economics, entrepreneurship, and several other disciplines. Second, this review was developed based on all the essential research variables. The results of this review are also expected to increase our understanding of how CE is achieved in family businesses and SMEs and the expected performance. Knowledge of these aspects will be beneficial in entrepreneurship discussions and learning, especially in the applied science of $\mathrm{CE}$, for both academics and family business actors and stakeholders in SMEs.

This article begins (Section 2) by explaining the methodology used in the research, starting with the selection of publications using the Scopus search engine, with the definition of keyword criteria, verification of the eligibility of articles, and determination of the selection of articles to be reviewed. The next section (Section 3) presents the results of the literature review, which are presented in the form of a table, and provides an explanation of each of the results. Then, we proceed with a discussion (Section 4) that discusses the review results, and the final section is the conclusions and future research (Section 5), which close this literature review.

The discussion in this review begins with a descriptive explanation of each article that was studied, including the year of publication, the country of research, the source of the publication, and the subject area of the research. We analyze descriptive data using content and bibliometric analysis. Then, the description is followed by a description of the theory or grand theory used in the research and the research methodology. 
Furthermore, this review places a greater emphasis on the integration of models from each article. We focus on three aspects: the first is the actors or principal role players in the organizations or companies for the occurrence of CE. Second, we consider EO activity and the behavior variable, and, thirdly, we consider the measurement of outcomes or results obtained from the research in each article. From the grouping results, we comprehensively discuss each variable and continue with discussions, conclusions, and suggestions for future research.

\section{Methodology}

The literature review in this research follows the three basic steps for a systematic literature review (SLR) according to (Tranfield et al. 2003), which states that a literature review should consist of planning, directing, and reporting the findings. The first stage of the research is to determine the objectives and roadmap of the review. Then, secondly, it is necessary to conduct a search and an in-depth study of the several articles that are obtained, and the last stage involves an in-depth study of the results. A conclusion is drawn and expressed in written form. This scientific study is also written based on (Massaro et al. 2015) and also derived from (Secundo et al. 2019), which states that the SLR approach is an approach that follows knowledge and contributes to the identification of research trends, with potential for future research.

This scientific study results from a synthesis of articles published from 2007 to July 2021 in Scopus in English, from various sources, such as Entrepreneurship Theory and Practice, the International Entrepreneurship and Management Journal, the Journal of Management Studies, and the International Journal of Entrepreneurship and Small Businesses. The subject areas in this research are Business, Management and Accounting, Economics, Econometrics and Finance, Decision Science, Social Science, Computer Science, Engineering, Agriculture and Biological Science, Art and Humanities, and Energy.

The decision to use the Scopus database was based on the fact that Scopus has the most prominent citations and contains more than 20,000 peer-reviewed journals (Mishra et al. 2017). Elsevier, Emerald, Taylor and Francis, and Springer are peer-reviewed from Scopus. In addition, Scopus is an extensive database for research in entrepreneurship, and it is highly recommended for use in this area (Bramer et al. 2017). The literature from the database in Scopus is appropriate for entrepreneurship research.

We searched Scopus using the keywords "corporate entrepreneurship" or "corporate entrepreneur", searching for article titles, abstracts, and keywords, and obtained 1040 articles. Then, conference papers, book chapters, reviews, books, editorials, errata, notes, retracted publications, and letters were identified (Keupp et al. 2012). Furthermore, only final articles in terms of publication and those written in English were selected, so there were 713 articles. A number of these articles were searched with a focus on "family business", "family firm", "SME", or "small and medium enterprise", and this identified 246 articles. From these articles, we read and checked the titles (Jongwe et al. 2020), abstracts, and issues, including literature review articles and meta-analyses, to ensure that there were no duplicates included. The final results regarding SLR totaled 53 articles. The review system of this article followed the literature review process of (Azila-Gbettor et al. 2018) and (Secundo et al. 2019), as illustrated in Figure 1.

The final data obtained from Scopus were transferred to a summary table using Microsoft Excel, which listed the bibliographic information and details regarding primary components, such as variables, theories used, methods, and all the data needed in the analysis. We used the VOSviewer tool to perform co-authorship, co-occurrence, and citation analysis to obtain the units of analysis from keywords, countries, and authors. The writing analysis and concept followed the SLR article of (Secundo et al. 2021). 


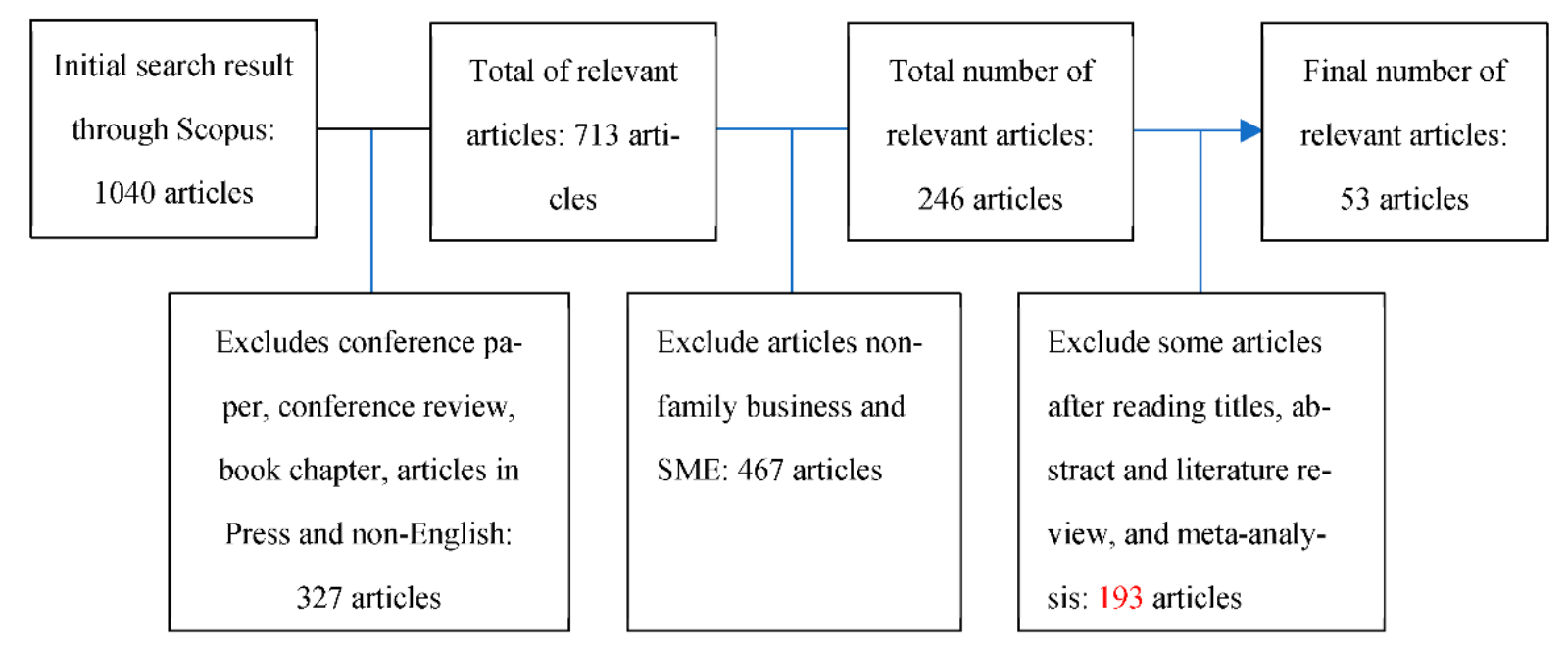

Figure 1. Steps for searching SLR articles.

The main aim of using this step was to analyze the time range, the state of the art of the literature, geography, journal sources, and variables. The variables consist of actors, attributes, and outcome measurements (Jongwe et al. 2020). According to (Secundo et al. 2019), we manually divided the result with some codes to identify the critical characteristics of the studies. Finally, we conducted content analysis to explore the theories used (Jongwe et al. 2020), as well as the methodologies, variables, research gaps, and future research directions.

\section{Results}

This section aims to explain the results of the literature analysis in order to answer this study's first two research questions, RQ1 and RQ2. The content of this section is divided into article description and article analysis.

\subsection{Article Description}

The next step was performed after obtaining 53 articles. An analysis of the search results in Scopus was carried out, including the documents per year, documents per source title, and documents per country, as shown in Table 2. The most publications were generated 2019 and 2021, amounting to 47.17 percent of the articles. However, there was potential for this value to be higher because we only included literature published prior to July 2021. At the beginning of this time range, between 2007 and 2009, the productivity amounted to only 5.66 percent. In the period 2013-2015, the percentage of productivity was 7.55 percent, while in the previous period, between 2010 and 2012, this value started to increase, reaching 15.09 percent.

Table 2. Analysis of search results based on Scopus.

\begin{tabular}{ccc}
\hline Document per Year & Number of Articles & Percentage \\
\hline Publication Per Year & 3 & \\
$2007-2009$ & 8 & 5.66 \\
$2010-2012$ & 4 & 15.09 \\
$2013-2015$ & 13 & 7.55 \\
$2016-2018$ & 25 & 24.53 \\
$2019-2021$ & 53 & 47.17 \\
Total articles & 100 \\
\hline
\end{tabular}


Geographical analysis of published articles considers the distribution of published articles by country and the relative citations by country (Figure 2). The criteria included in VOSviewer are a minimum number of four articles and four citations in one country. In this analysis, we found eight countries with the highest number of articles, the United States with eleven articles, and the UK with seven articles. The highest number of citations came from the USA, with 328 citations, and the second highest was from Germany, with 193 citations. For Asian countries, the most articles were from Malaysia, with 5 articles with 46 citations, and Iran, with 5 articles with 28 citations.

The following analysis considered the publication sources of several articles in the study, with the criteria of a minimum number of two articles and two citations for each source (Figure 3). The data indicated that the most prevalent sources were Entrepreneurship: Theory and Practice, the Journal of Management Studies, and the International Entrepreneurship and Management Journal, with as many as three articles. The highest number of citations was generated by Entrepreneurship: Theory and Practice, with 172 citations, followed by the Journal of International Entrepreneurship, with 82 citations, and the International Entrepreneurship and Management Journal, with 54 citations.

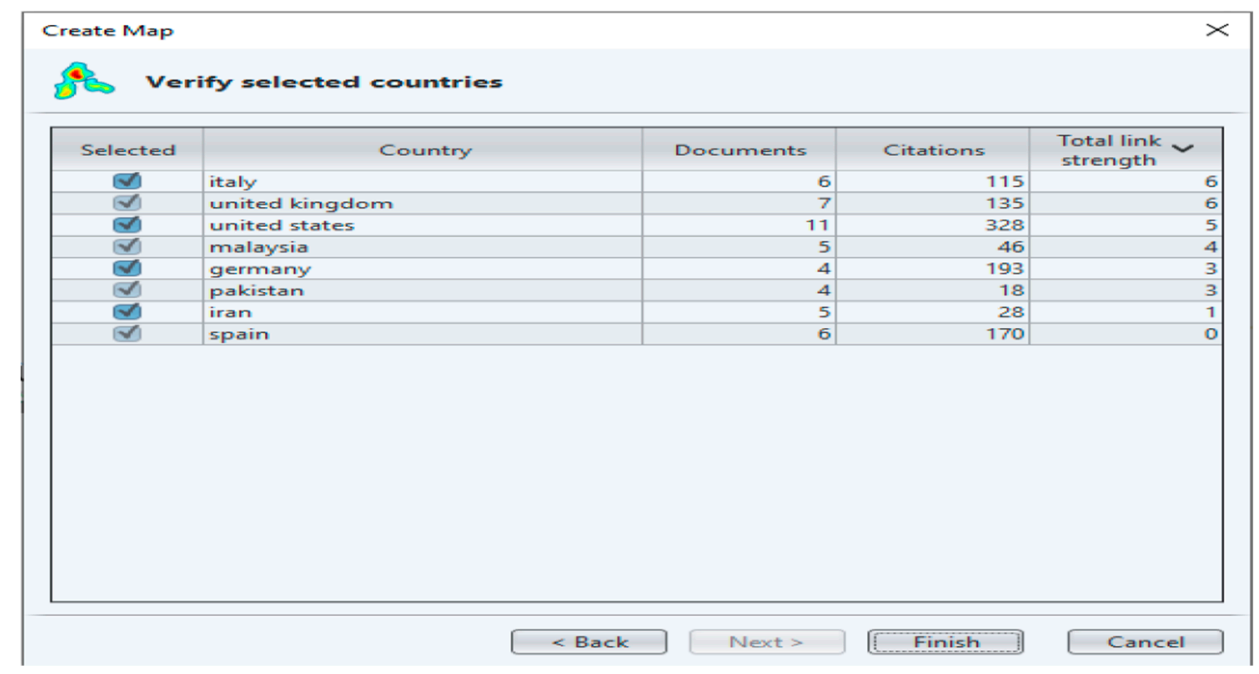

Figure 2. Documents and citations of selected countries (VOSviewer elaboration).

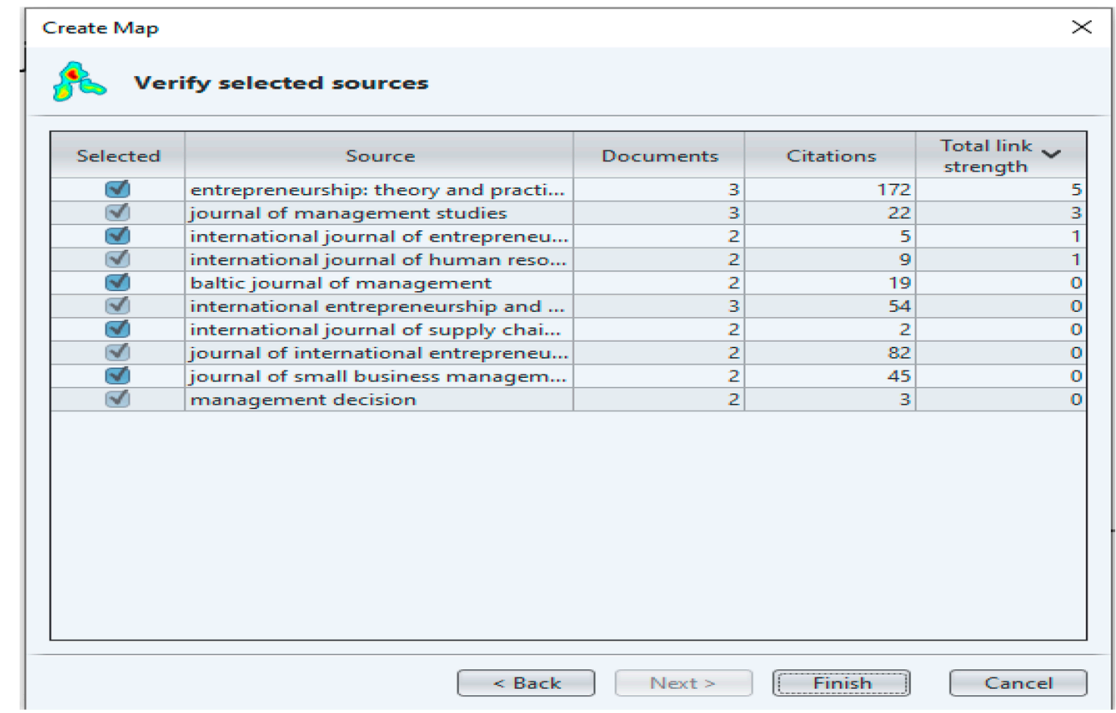

Figure 3. Documents and citations of selected sources (VOSviewer elaboration). 
In order to identify the most common keywords in the articles that we studied, we analyzed keyword occurrences using VOSviewer. We used co-occurrence analysis, and the unit of analysis was author keywords with a minimum number of occurrences per keyword of at least two. In total, we obtained 21 keywords out of 165 keywords. The most prevalent keyword was corporate entrepreneurship, with 34 occurrences, followed by family business, with 8 occurrences. The data for the selected keywords and occurrences can be seen in Figure 4 and are illustrated by the VOSviewer visualization in Figure 5.

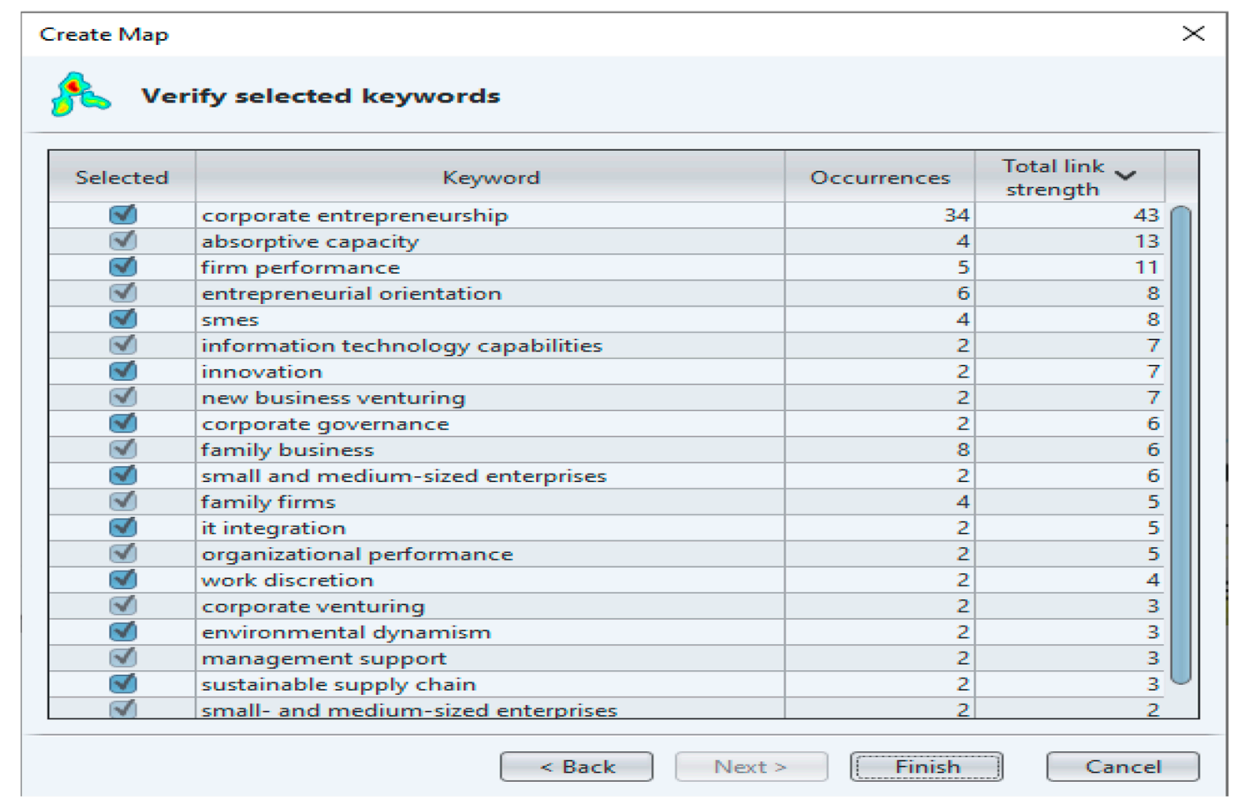

Figure 4. Occurrence of selected author keywords.

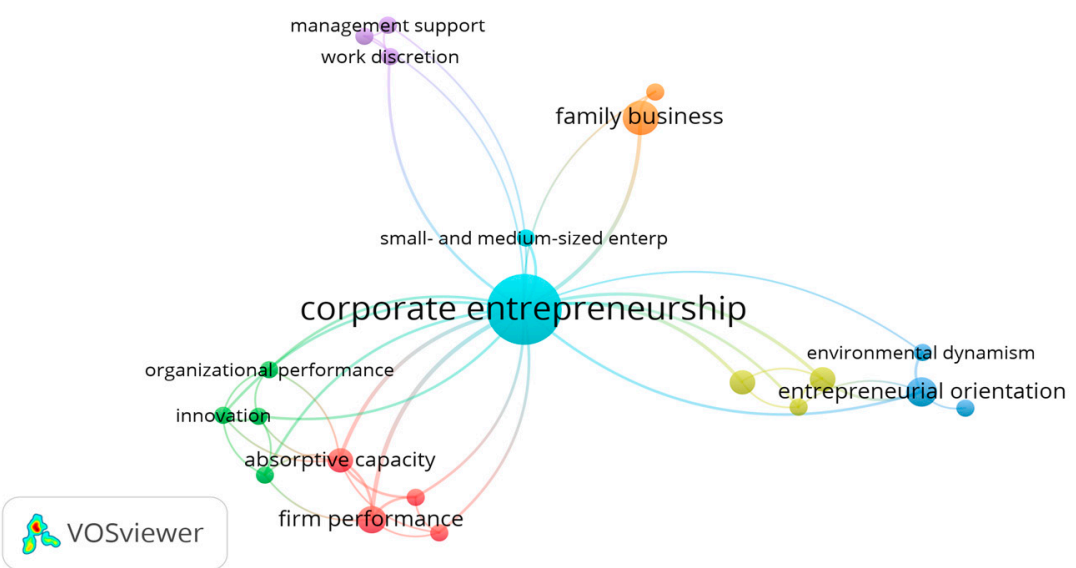

Figure 5. Author keyword visualization.

Next, we considered the research methodology. Quantitative research was still dominant, amounting to 77.36 percent, and research with qualitative approaches constituted 15.09 percent. The remaining articles used mixed-methods research, which involves a mixture of quantitative and qualitative methods. An explanation of the theoretical analysis and methodology used can be seen in Table 3. 
Table 3. Most common research methodologies and theories.

\begin{tabular}{lcc}
\hline Research Approach & Number of Articles & Percentage \\
\hline Quantitative & 41 & 77.36 \\
Qualitative & 8 & 15.09 \\
Mixed Methods & 4 & 7.55 \\
Total & 53 & 100 \\
\hline Theory & Number of Articles & Percentage \\
\hline Single theory & 30 & 73.17 \\
Multiple theories & 11 & 26.83 \\
Total & 41 & 100 \\
\hline
\end{tabular}

Each article was identified based on whether it used a single theory or multiple theories (Azila-Gbettor et al. 2018). The use of a single theory is still very dominant in research, representing 73.17 percent of articles, and multiple theories were used in 26.83 percent, as seen in Table 3. Organization theory was the single most widely used theory in the research (Leal-Rodríguez et al. 2017; Aeknarajindawat 2020; Rehman et al. 2020). Regarding multiple theories, the most widely used were agency theory and stewardship theory (Amberg and McGaughey 2019; Kotlar and Sieger 2019; Lee et al. 2019; Bui et al. 2020). An explanation of the theories is given below in Table 4.

Table 4. Description of theory focus.

\begin{tabular}{|c|c|}
\hline Single Theory & Multiple Theory \\
\hline Behavioral theory (Fang et al. 2021) & Resource-based view theory and institutional theory \\
\hline Prevailing theory (Soares et al. 2021) & (Ziyae and Sadeghi 2020) \\
\hline Prospect theory (Fang et al. 2021) & Behavioral theory and social comparison theory \\
\hline Family system theory (Raitis et al. 2021) & (Thomas et al. 2020) \\
\hline Contingency theory (De Massis et al. 2021) & Resource-based and agency theory (Fu and Si 2018; \\
\hline Stakeholder theory (Chienwattanasook et al. 2019; Saleem et al. 2020) & Asogwa et al. 2020) \\
\hline Complementarity based theory (Rehman et al. 2020) & Agency theory and dynamic capability theory \\
\hline Social exchange theory (Sakhdari et al. 2020) & (García-Sánchez et al. 2018) \\
\hline Gender theory (Franco and Piceti 2020) & Agency theory and stewardship theory (Amberg and \\
\hline $\begin{array}{l}\text { Organization theory (Leal-Rodríguez et al. 2017; Nabeel-Rehman and } \\
\text { Nazri 2019; Sriviboon 2020) }\end{array}$ & $\begin{array}{l}\text { McGaughey 2019; Kotlar and Sieger 2019; Lee et al. 2019; } \\
\text { Bui et al. 2020) }\end{array}$ \\
\hline $\begin{array}{c}\text { Network theory of entrepreneurship (Riviezzo and Garofano 2018; } \\
\text { Akbari et al. 2020) }\end{array}$ & $\begin{array}{c}\text { Agency theory and transaction cost theory (Ndemezo } \\
\text { and Kayitana 2018) }\end{array}$ \\
\hline Knowledge based resources theory (Bojica et al. 2017; Akbari et al. 2020) & Agency theory, stewardship theory and resource-based \\
\hline The classic theory of management (Noerhartati et al. 2020) & theory (Calabrò et al. 2016) \\
\hline Social information processing theory (Liu et al. 2020) & Leadership and agency theory (Ling et al. 2008) \\
\hline Leadership theory (Boukamcha 2019) & \\
\hline \multicolumn{2}{|l|}{ Echelon theory (Afshar Jahanshahi et al. 2018) } \\
\hline \multicolumn{2}{|l|}{ Network theory (Hosseini et al. 2018) } \\
\hline \multicolumn{2}{|l|}{ Institutional theory (Toledano et al. 2010; Hughes and Mustafa 2017) } \\
\hline \multicolumn{2}{|l|}{ Dynamic capabilities theory (Martín-Rojas et al. 2017) } \\
\hline \multicolumn{2}{|l|}{ Time, interaction, and Performance (TIP) theory } \\
\hline \multicolumn{2}{|l|}{ (Chen and Nadkarni 2017) } \\
\hline \multicolumn{2}{|l|}{ Stewardship theory (Eddleston et al. 2012) } \\
\hline \multicolumn{2}{|l|}{ Entrepreneurship theory (Hancer et al. 2009; Marchisio et al. 2010; Van } \\
\hline \multicolumn{2}{|l|}{ Wyk and Adonisi 2012; Garrett and Welcher 2018; Najmulmunir 2020) } \\
\hline \multicolumn{2}{|l|}{ Business model innovation theory (Cucculelli and Bettinelli 2015) } \\
\hline \multicolumn{2}{|l|}{ Stevenson's theory (Naldi et al. 2015) } \\
\hline \multicolumn{2}{|l|}{ System theory (Schmelter et al. 2010) } \\
\hline International corporate entrepreneurial theory & \\
\hline (Ripollés-Meliá et al. 2007) & \\
\hline
\end{tabular}




\subsection{Articles Analysis}

Article analysis was concluded by dividing the articles based on the actors (first column), attributes (second column), and outcomes (third column). The analysis of all articles is presented in Table 5 .

Table 5. Corporate entrepreneurship variables.

\begin{tabular}{|c|c|c|}
\hline Actors & Attributes & Outcomes \\
\hline $\begin{array}{l}\text { Chairman/CEO/Director: } 11 \text { articles } \\
\text { (Ling et al. 2008; Cucculelli and Bettinelli } \\
\text { 2015; Naldi et al. 2015; Calabrò et al. 2016; } \\
\text { Chen and Nadkarni 2017; Hughes and } \\
\text { Mustafa 2017; García-Sánchez et al. 2018; } \\
\text { Riviezzo and Garofano 2018; Rehman } \\
\text { et al. 2020; Saleem et al. 2020; De Massis } \\
\text { et al. 2021) } \\
\text { Employees/Staff: } 12 \text { articles } \\
\text { (Ripollés-Meliá et al. 2007; Toledano et al. } \\
\text { 2010; Kuye et al. 2012; Bojica et al. 2017; } \\
\text { Chienwattanasook et al. 2019; } \\
\text { Aeknarajindawat 2020; Liu et al. 2020; } \\
\text { Najmulmunir 2020; Noerhartati et al. } \\
\text { 2020; Rehman et al. 2020; Ziyae and } \\
\text { Sadeghi 2020; Raitis et al. 2021) } \\
\text { Manager/TMT: 19 articles (Hancer et al. } \\
\text { 2009; Schmelter et al. 2010; Van Wyk and } \\
\text { Adonisi 2012; Mustafa et al. 2013; } \\
\text { Leal-Rodríguez et al. 2017; Martín-Rojas } \\
\text { et al. 2017; Afshar Jahanshahi et al. 2018; } \\
\text { Hosseini et al. 2018; Ndemezo and } \\
\text { Kayitana 2018; Amberg and McGaughey } \\
\text { 2019; Boukamcha 2019; Kotlar and Sieger } \\
\text { 2019; Lee et al. 2019; Soliman 2019; } \\
\text { Akbari et al. 2020; Garrett et al. 2020; } \\
\text { Sakhdari et al. 2020; De Massis et al. 2021; } \\
\text { Soares et al. 2021) } \\
\text { Family Members/Owner: 6 articles } \\
\text { (Marchisio et al. 2010; Hughes and } \\
\text { Mustafa 2017; Fu and Si 2018; Franco and } \\
\text { Piceti 2020; Saleem et al. 2020; Fang et al. } \\
\text { 2021) }\end{array}$ & $\begin{array}{l}\text { CE activities such as venturing, } \\
\text { innovation and strategic renewal: } 12 \\
\text { articles (Toledano et al. 2010; Cucculelli } \\
\text { and Bettinelli 2015; Calabrò et al. 2016; } \\
\text { Hughes and Mustafa 2017; } \\
\text { Leal-Rodríguez et al. 2017; Martín-Rojas } \\
\text { et al. 2017; Kotlar and Sieger 2019; Lee } \\
\text { et al. 2019; Soliman 2019; Garrett et al. } \\
\text { 2020; Sakhdari et al. 2020; De Massis et al. } \\
\text { 2021) } \\
\text { Company factors of CE such as } \\
\text { management support, work discretion, } \\
\text { reward/reinforcement, time availability, } \\
\text { and organization boundaries: } 6 \text { articles } \\
\text { (Kuye et al. 2012; Mustafa 2015; } \\
\text { Chienwattanasook et al. 2019; Akbari } \\
\text { et al. 2020; Najmulmunir 2020; } \\
\text { Noerhartati et al. 2020) } \\
\text { Entrepreneur orientation such as risk } \\
\text { taking, innovativeness, proactiveness, } \\
\text { aggressiveness, and autonomy: } 8 \text { articles } \\
\text { (Hancer et al. 2009; Toledano et al. 2010; } \\
\text { Eddleston et al. 2012; Riviezzo and } \\
\text { Garofano 2018; Liu et al. 2020; Rehman } \\
\text { et al. 2020; Ziyae and Sadeghi 2020; Fang } \\
\text { et al. 2021) } \\
\text { Personnel and family concern such as } \\
\text { owner gender, education, experience, } \\
\text { knowledge, transformational CEOs } \\
\text { influence, TMTs' behavioral integration, } \\
\text { age, and tenure: } 8 \text { articles (Saleem et al. } \\
\text { 2020; Ling et al. 2008; Chen and Nadkarni } \\
\text { 2017; Fu and Si 2018; Ndemezo and } \\
\text { Kayitana 2018; Riviezzo and Garofano } \\
\text { 2018; Bui et al. 2020; Thomas et al. 2020) } \\
\text { Human resource concerns, such as } \\
\text { employee satisfaction, organization } \\
\text { commitment, motivation, cultural } \\
\text { intelligence, tolerance of ambiguity, CEO } \\
\text { style, high-performance human resources, } \\
\text { organizational culture, and education: } 8 \\
\text { articles (Mustafa et al. 2013; Soleimani } \\
\text { and Shahnazari 2013; Naldi et al. 2015; } \\
\text { Afshar Jahanshahi et al. 2018; Boukamcha } \\
\text { 2019; Aeknarajindawat 2020; Franco and } \\
\text { Piceti 2020; Soares et al. 2021) }\end{array}$ & $\begin{array}{l}\text { Financial performance such as ROA, } \\
\text { ROE, sales growth, net profit, and sales } \\
\text { growth: } 9 \text { articles (Marchisio et al. 2010; } \\
\text { Toledano et al. 2010; Naldi et al. 2015; } \\
\text { Bojica et al. 2017; Leal-Rodríguez et al. } \\
\text { 2017; Fu and Si 2018; Rehman et al. 2020; } \\
\text { Sakhdari et al. 2020; Fang et al. 2021) } \\
\text { Organization and company performance } \\
\text { such as exploitation of new resources, } \\
\text { resources new market, creating new } \\
\text { business/service/product, competitive } \\
\text { advantage, intangible: 16 articles } \\
\text { (Eddleston et al. 2012; Cucculelli and } \\
\text { Bettinelli 2015; Martín-Rojas et al. 2017; } \\
\text { García-Sánchez et al. 2018; Riviezzo and } \\
\text { Garofano 2018; Amberg and McGaughey } \\
\text { 2019; Boukamcha 2019; } \\
\text { Chienwattanasook et al. 2019; Lee et al. } \\
\text { 2019; Nabeel-Rehman and Nazri 2019; } \\
\text { Soliman 2019; Akbari et al. 2020; Franco } \\
\text { and Piceti 2020; Thomas et al. 2020; Ziyae } \\
\text { and Sadeghi 2020; De Massis et al. 2021) } \\
\text { Family value such as family business } \\
\text { tradition, family business sustainability: } \\
3 \text { articles (Soares et al. 2021; Raitis et al. } \\
\text { 2021; Soleimani and Shahnazari 2013) } \\
\text { CE performance such as enhancing } \\
\text { innovation and creativity, innovation: 13 } \\
\text { articles (Saleem et al. 2020; Bui et al. 2020; } \\
\text { Liu et al. 2020; Ling et al. 2008; Hancer } \\
\text { et al. 2009; Kuye et al. 2012; Mustafa et al. } \\
\text { 2013; Calabrò et al. 2016; Chen and } \\
\text { Nadkarni 2017; Afshar Jahanshahi et al. } \\
\text { 2018; Hosseini et al. 2018; Ndemezo and } \\
\text { Kayitana 2018; Rehman et al. 2020) } \\
\text { CE factors such as MS, } \\
\text { reward/compensation, WD, TA, OB } 2 \\
\text { articles (Hughes and Mustafa 2017; Van } \\
\text { Wyk and Adonisi 2012) } \\
\text { Personnel performance such as } \\
\text { performance-based reward systems: } 2 \\
\text { articles (Kotlar and Sieger 2019; Mustafa } \\
\text { et al. 2013) } \\
\text { Supply chain performance: } 2 \text { articles } \\
\text { (Najmulmunir 2020; Noerhartati et al. } \\
\text { 2020) }\end{array}$ \\
\hline
\end{tabular}


Table 5. Cont.

\begin{tabular}{|c|c|c|}
\hline Actors & Attributes & Outcomes \\
\hline & $\begin{array}{l}\text { Internal organizational factors, such as } \\
\text { market orientation, flexibility and job } \\
\text { satisfaction, different management } \\
\text { functions, and work value: } 3 \text { articles (Van } \\
\text { Wyk and Adonisi 2012; Hosseini et al. } \\
\text { 2018; Raitis et al. 2021) } \\
\text { Company support, such as IT integration, } \\
\text { technological skill, and fire safety: } 5 \\
\text { articles (Schmelter et al. 2010; } \\
\text { García-Sánchez et al. 2018; Amberg and } \\
\text { McGaughey 2019; Nabeel-Rehman and } \\
\text { Nazri 2019; Rehman et al. 2020) }\end{array}$ & $\begin{array}{l}\text { Market performance } 1 \text { article (Garrett } \\
\text { et al. 2020) } \\
\text { Entrepreneurial orientation: } 1 \text { article } \\
\text { (Schmelter et al. 2010) }\end{array}$ \\
\hline
\end{tabular}

\subsubsection{Actors Focus Analysis}

Actors in CE implementation are represented by several protagonists, including the founder/CEO, TMT, middle manager, broad advisors, and family (Schindehutte et al. 2018). The analyzed actors were divided into four categories: Chairman/CEO/Director, Employees/Staff, Manager/TMT, and Family Member/Owner. The most frequently investigated actors were managers and TMTs, with 19 articles, followed by employees/staff, with 12 articles. Interestingly, the actor category of family member/owner was only included in six articles, including the research (Marchisio et al. 2010; Hughes and Mustafa 2017; Fu and Si 2018; Franco and Piceti 2020; Saleem et al. 2020; Fang et al. 2021). Meanwhile, the CEO/chairman/director category was considered in eleven articles (Ling et al. 2008; Cucculelli and Bettinelli 2015; Naldi et al. 2015; Calabrò et al. 2016; Chen and Nadkarni 2017; Hughes and Mustafa 2017; García-Sánchez et al. 2018; Riviezzo and Garofano 2018; Rehman et al. 2020; Saleem et al. 2020; De Massis et al. 2021).

\subsubsection{Attribute Focus Analysis}

The attribute variables as the driving motivation for CE were mostly venturing, innovation, and strategic renewal, with eleven articles, followed by entrepreneur orientation variables such as risk-taking, innovativeness, proactiveness, aggressiveness, and autonomy, and, finally, personnel and family concern variables, such as owner gender, education, experience, knowledge, transformational CEO influence, TMTs' behavioral integration, age, and tenure, with eight articles each. Those directly related to CE attributes were company factors of CE, such as management support, work discretion, reward/reinforcement, time availability, and organization boundaries, and these were included in only six articles (Kuye et al. 2012; Mustafa 2015; Chienwattanasook et al. 2019; Akbari et al. 2020; Najmulmunir 2020; Noerhartati et al. 2020).

\subsubsection{Outcomes Focus Analysis}

The outcomes of this research were organization and company performance, such as the exploitation of new resources, the identification of new market resources, the creation of a new business/service/product, and competitive advantage, which constituted 16 articles. Furthermore, the second highest was CE performance, such as enhancing innovation, creativity, and innovation, with 13 articles. The third most prevalent focus was financial performance, such as ROA, ROE, sales growth, and net profit, with as many as eight articles. There was only one article discussing market performance (Garrett et al. 2020) and one article discussing EO (Schmelter et al. 2010). 


\section{Discussion}

This section aims to discuss and critique the main findings in order to answer RQ3 and RQ4. It is divided into two subsections for clarity.

\subsection{Developing CE in Family Business and SMEs}

The review conducted in this study can explain the concept of CE with regard to family businesses and SMEs, which is developed according to the three variables in Table 5, each of which is explained in terms of its position and function. The three variables are actors, attributes, and outcomes. All variables in the empirical data from the study have been included. From the articles that have been discussed, it is found that the development is complete for each variable, and only in terms of attributes were the complete functions not fully explained. Motivation is another interesting factor to discuss in relation to CE but was not found in the studied articles.

From the analysis of the actors in the company, there is a contradiction if the actor holds two positions or a dual role, including as CEO and as an operational-level manager, which does not lead to higher entrepreneurial activity. This empirical study emphasizes that if one person holds two different positions within a company, then there is a risk that $\mathrm{CE}$ will fail. Further analysis is given in (Asogwa et al. 2020), which states that many boards of directors, including the CEO, will affect the company's performance. Furthermore, it describes the appropriate number and role for each family business and SME in the implementation of CE.

The development of performance outcomes has also not been fully carried out by researchers in CE focusing on family businesses and SMEs. The outcomes also vary significantly from financial to non-financial performance, and the most widely explored outcomes are organization and company performance. Some have used financial performance, which has been very clearly stated; however, for non-financial performance, the indicators are still not clearly stated. A significant undertaking would also be to consider the interaction between $\mathrm{CE}$ and the social performance variable. This finding also shows that further elaboration of the relationship between CE in family businesses and SMEs is needed.

According to the empirical research of (Marchisio et al. 2010), a positive financial impact can be achieved by increasing corporate venturing and reducing the risk of cohesion in the family circle within a family business. On the other hand, (Soares et al. 2021) stated that in order to ensure the sustainability of a family business, entrepreneurship education is needed for all family members, and investment in CE education will add value to the family business. Sustainability in a family business contributes to its actual performance, and, in addition to $C E$ activities, investing in entrepreneurial education is necessary.

The study by (Hosseini et al. 2018) shows that entrepreneurial orientation negatively impacts performance. Factors associated with entrepreneurial orientation include risktaking and innovativeness. In contradiction with the study (Leal-Rodríguez et al. 2017; Rehman et al. 2020), innovation has a positive correlation with performance. Performance is the goal for every family business and SME engaging in CE activities, including new venturing and investment for a family member, which is important in the entrepreneurship field. Investment in innovation is an essential factor for SMEs and family businesses. It is crucial to better understand the relationship between investment in innovation and the competitiveness of SMEs (Lewandowska 2021). In terms of investment innovation, an innovative company increases their chances of improving competitiveness compared to a non-innovative company (Lewandowska 2021). Interestingly, innovation and investment are critical points in SMEs and family businesses in developing their CE activities. Investment requires costs, and the cost is always a major concern for SMEs and family businesses. A contradiction may arise when investment and innovation have one purpose-to achieve better performance-while funding remains an important issue.

The concepts in the literature described in Table 5 consist of three variables, the first being four types of drivers, namely, chairman/CEO/director, employees/staff, manager/TMT, and family member/owner, as described in Table 5 (column 1). Second, there 
are seven types of attributes, namely, CE activities (12 articles), company factors of CE (6 articles), entrepreneur orientation (8 articles), personnel and family concerns (8 articles), human resource concerns (8 articles), internal organizational issues ( 3 articles), and company support (5 articles), which are also described in Table 5 (column 2). The third variable is the outcomes, which consist of nine types, namely, financial performance ( 9 articles), organization and company performance (16 articles), family value (3 articles), CE performance (13 articles), CE factors ( 2 articles), personnel performance (2 articles), supply chain performance ( 2 articles), market performance ( 1 article), and EU performance (1 article), as described in Table 5 (column 3). The representation of all aspects in the existing variables may not be complete. There is still much potential to be considered, and this will be a new aspect for further research in the field of CE in family businesses and SMEs.

The development of CE research in terms of the actors that shape the occurrence of $\mathrm{CE}$ in family businesses and SMEs is complete, and several articles consider many actors, from employees to upper management and owners. Some researchers have made contributions using a multilayer model of the actor of CE, including the CEO and the family members in the company, thus offering a deeper and more refined understanding of the causal relationship between the actors to maximize the CE activities (Toledano et al. 2010; Mustafa et al. 2013; Saleem et al. 2020). This is an important contribution and very representative of constructive research results, as the researchers did not depend on only one level in examining CE in family companies and SMEs.

The results of the analysis of the distribution of the three variables show that the representation of actors/drivers is reasonably even across all studies, and managers/TMTs are the most dominant. All individual sectors have been represented in the study, and the most dominant is the attribute of CE activities.

\subsection{The Theories in Literature of CE in Family Business and SMEs}

Finally, to answer the last research question, QU, regarding to the theories used in the studied articles, most used a single theory, and some articles did not clearly state the theory used. One of the major theories in the previous articles was agency theory, and agency theory was always combined with other theories. No articles specifically mentioned agency theory as a single theory. Agency theory was combined with dynamic capability theory (García-Sánchez et al. 2018), stewardship theory (Amberg and McGaughey 2019; Kotlar and Sieger 2019; Lee et al. 2019; Bui et al. 2020), transaction cost theory (Ndemezo and Kayitana 2018), and stewardship theory and resource-based theory (Calabrò et al. 2016).

Regarding the level of a firm's CE, agency theory points to corporate governance as one organizational factor (Romero-Martínez et al. 2010). In the literature, the studies used agency theory only in regard to large companies and not in reference to family businesses or SMEs. According to the basic agency theory (Jensen and Meckling 1976), the relationship between the principal and agent relies on the work contract. The principal is the shareholder or the owner, and the agent is the employee or management team. The concept of agency theory is the most dominant organizational theory perspective within family business research (Chrisman et al. 2010). We encourage future research to use the single theory, agency theory, to expand the frontiers of the theory's application in the field of family businesses and SMEs. Other opportunities to explore single theories such as stewardship theory and resource-based theory are possible in the CE field and could pave the way towards adopting a new theoretical approach in CE for family businesses and SMEs.

\section{Conclusions and Future Research}

The results of the systematic processing of literature reviews from corporate entrepreneurship research that is focused on family companies and small-medium enterprises produce a multidimensional concept with several variables, including actors, attributes (motivation and activities), and consequences or outcomes. The study used 53 Scopus articles from the period of 2007-2021 from various countries, dominated by the United 
States, Europe, and Asia. Research in developing countries is still sparse. For 14 years, research in CE in family businesses and SMEs has not been extensively carried out worldwide, according to Scopus; despite this, positive growth trends were registered during 2019-2021. However, for developing countries, the research is still lacking. It is highly recommended that future research be conducted on CE in family businesses and SMEs in developing countries. Family businesses and SMEs in developing countries are the main factors driving their development. This is also important considering that developing countries likely contain many interesting family businesses and SMEs to explore in CE.

Research on CE in family businesses and small companies is still relatively rare and only focuses on large companies or large multinational companies. In the previous studies, CE research focused on large companies, multinational corporations, and particular industries. Opportunities for conducting research in CE for family businesses and SMEs are still numerous for this community of scholars and researchers. Exploring such issues through theoretical and empirical contributions in family businesses and SMEs would be a promising avenue of future research.

The research method used was still mostly quantitative research, and research with a qualitative approach was still very rare. Research with qualitative methods is possible if the data on the number of samples used are not significant, and this can be carried out similarly to a case study model for only a few companies. The main problem is the difficulty of conducting research on family businesses and SMEs using qualitative methods. The methods of in-depth interviews and internal exploration of the experts who are the key actors within their companies are challenging.

There are not many instances of research in which family members of the company are regarded as actors in the study. Research on family businesses could be comprehensive if there is involvement from family members and owners, and this could be considered in further research in the future. Scholars in the family business field have not explored the correlations among relatives as actors in the family business. According to these gaps, there are many topics and opportunities for future research in $\mathrm{CE}$ in family businesses.

We believe that research on $\mathrm{CE}$ in family businesses will bring many benefits for entrepreneurs to raise the level of their companies from an established family business to a more reputable company. This SLR research contributes to further research demonstrating the potential for novelty in $\mathrm{CE}$ in family businesses, especially regarding entrepreneurship. We hope that the results of articles or studies on research on CE in family businesses will be included in journals that are recognized and have a significant impact in terms of entrepreneurship so that they are helpful for academics and practitioners.

This study also has several limitations that affect the results of the literature review. The use of the corporate entrepreneurship keyword and the deepening of articles based on family businesses and SME were limited to journals indexed by Scopus, resulting in the possibility that many articles suitable for review were not included. Suggestions for further research include adding references from several other publication sources, especially to increase the depth of $\mathrm{CE}$ research from the family business side. We hope that the results of articles or studies on research on CE in family businesses and SMEs will be included in prominent, high-impact journals such as Scopus in the future.

Funding: This research received no external funding.

Conflicts of Interest: The authors declare no conflict of interest.

\section{References}

Aeknarajindawat, Natnaporn. 2020. Safety Climate Impact on the Safety Behavior in Chemical Industry of Thailand. Journal of Security and Sustainability 9: 96-107. [CrossRef]

Afshar Jahanshahi, Asghar, Khaled Nawaser, and Alexander Brem. 2018. Corporate Entrepreneurship Strategy: An Analysis of Top Management Teams in SMEs. Baltic Journal of Management 13: 528-43. [CrossRef] 
Akbari, Morteza, Kamal Sakhdari, and Mozhgan Danesh. 2020. Organizational preparedness for corporate entrepreneurship and performance in Iranian food industry. Journal of Agriculture, Science and Technology 22: 361-75. Available online: https: / / www. scopus.com/inward/record.uri?eid=2-s2.0-85081019512\&partnerID=40\&md5=b028fdccf150dc638276033d780335d9 (accessed on 10 October 2021).

Amberg, Joe J., and Sara L. McGaughey. 2019. Strategic Human Resource Management and Inertia in the Corporate Entrepreneurship of a Multinational Enterprise. International Journal of Human Resource Management 30: 759-93. [CrossRef]

Asogwa, Cosmas Ikechukwu, Osmund Chinweoda Ugwu, Anthonia Uju Uzuagu, Samson Ige Abolarinwa, Godwin Keres Okoro Okereke, Honesta Chidiebere Anorue, and Favour Amarachi Moghalu. 2020. Absorptive Capacity, Business Venturing and Performance: Corporate Governance Mediating Roles. Cogent Business and Management 7: 1-41. [CrossRef]

Azila-Gbettor, Edem M., Ben Q. Honyenuga, Marta M. Berent-Braun, and Ad Kil. 2018. Structural Aspects of Corporate Governance and Family Firm Performance: A Systematic Review. Journal of Family Business Management 8: 306-30. [CrossRef]

Bojica, Ana Maria, María del Mar Fuentes-Fuentes, and Virginia Fernández Pérez. 2017. Corporate Entrepreneurship and Codification of the Knowledge Acquired from Strategic Partners in SMEs. Journal of Small Business Management 55: 205-30. [CrossRef]

Boukamcha, Fayçal. 2019. The Effect of Transformational Leadership on Corporate Entrepreneurship in Tunisian SMEs. Leadership and Organization Development Journal 40: 286-304. [CrossRef]

Bramer, Wichor M., Melissa L. Rethlefsen, Jos Kleijnen, and Oscar H. Franco. 2017. Optimal Database Combinations for Literature Searches in Systematic Reviews: A Prospective Exploratory Study. Systematic Reviews 6: 1-12. [CrossRef] [PubMed]

Bui, Hong T. M., Huong T. M. Nguyen, and Vinh Sum Chau. 2020. Strategic Agility Orientation? The Impact of CEO Duality on Corporate Entrepreneurship in Privatized Vietnamese Firms. Journal of General Management 45: 107-16. [CrossRef]

Burger, Lennart, and Ivana Blažková. 2020. Internal Determinants Promoting Corporate Entrepreneurship in Established Organizations: A Systematic Literature Review. Central European Business Review 9: 19-45. [CrossRef]

Calabrò, Andrea, Tommaso Minola, Giovanna Campopiano, and Thilo Pukall. 2016. Turning Innovativeness into Domestic and International Corporate Venturing: The Moderating Effect of High Family Ownership and Influence. European Journal of International Management 10: 505-33. [CrossRef]

Chen, Jianhong, and Sucheta Nadkarni. 2017. It's about Time! CEOs' Temporal Dispositions, Temporal Leadership, and Corporate Entrepreneurship. Administrative Science Quarterly 62: 31-66. [CrossRef]

Chienwattanasook, Krisada, Samanan Wattanapongphasuk, Andi Luhur Prianto, and Kittisak Jermsittiparsert. 2019. Corporate Entrepreneurship and Business Performance of Logistic Companies in Indonesia. Industrial Engineering and Management Systems 18: 541-50. [CrossRef]

Chrisman, James J., Franz W. Kellermanns, Kam C. Chan, and Kartono Liano. 2010. Intellectual Foundations of Current Research in Family Business: An Identification and Review of 25 Influential Articles. Family Business Review 23: 9-26. [CrossRef]

Cucculelli, Marco, and Cristina Bettinelli. 2015. Business Models, Intangibles and Firm Performance: Evidence on Corporate Entrepreneurship from Italian Manufacturing SMEs. Small Business Economics 45: 329-50. [CrossRef]

De Massis, Alfredo, Kimberly A. Eddleston, and Paola Rovelli. 2021. Entrepreneurial by Design: How Organizational Design Affects Family and Non-Family Firms' Opportunity Exploitation. Journal of Management Studies 58: 27-62. [CrossRef]

Eddleston, Kimberly A., Franz W. Kellermanns, and Thomas M. Zellweger. 2012. Exploring the Entrepreneurial Behavior of Family Firms: Does the Stewardship Perspective Explain Differences? Entrepreneurship: Theory and Practice 36: 347-67. [CrossRef]

Fang, Hanqing Chevy, Esra Memili, James J. Chrisman, and Linjia Tang. 2021. Narrow-Framing and Risk Preferences in Family and Non-Family Firms. Journal of Management Studies 58: 201-35. [CrossRef]

Franco, Mário, and Patricia Piceti. 2020. Family Dynamics and Gender Perspective Influencing Copreneurship Practices: A Qualitative Analysis in the Brazilian Context. International Journal of Entrepreneurial Behaviour and Research 26: 14-33. [CrossRef]

Fu, Ying, and Steven Si. 2018. Does a Second-Generation Returnee Make the Family Firm More Entrepreneurial?: The China Experience. Chinese Management Studies 12: 287-304. [CrossRef]

García-Sánchez, Encarnacion, Víctor Jesús García-Morales, and Rodrigo Martín-Rojas. 2018. Analysis of the Influence of the Environment, Stakeholder Integration Capability, Absorptive Capacity, and Technological Skills on Organizational Performance through Corporate Entrepreneurship. International Entrepreneurship and Management Journal 14: 345-77. [CrossRef]

Garrett, Robert P., and Tommie Welcher. 2018. Corporate Entrepreneurship as a Survival Routine. Advances in the Study of Entrepreneurship, Innovation, and Economic Growth 28: 111-22. [CrossRef]

Garrett, Robert, Shaunn Mattingly, Jeff Hornsby, and Alireza Aghaey. 2020. Impact of Relatedness, Uncertainty and Slack on Corporate Entrepreneurship Decisions. Management Decision 59: 1114-31. [CrossRef]

Gedajlovic, Eric, Michael H. Lubatkin, and William S. Schulze. 2004. Crossing the Threshold from Founder Management to Professional Management: A Governance Perspective. Journal of Management Studies 41: 899-912. [CrossRef]

Gonzalez, Maximiliano, Juan David Idrobo, and Rodrigo Taborda. 2019. Family Firms and Financial Performance: A Meta-Regression Analysis. Academia Revista Latinoamericana de Administracion 32: 345-72. [CrossRef]

Guth, William D., and Ari Ginsberg. 1990. Guest Editors' Introduction: Corporate Entrepreneurship. Strategic Management Journal 11: $5-15$.

Hancer, Murat, Ahmet Bulent Ozturk, and Tugrul Ayyildiz. 2009. Middle-level hotel managers' corporate entrepreneurial behavior and risk-taking propensities: A case of didim, Turkey. Journal of Hospitality and Leisure Marketing 18: 523-37. [CrossRef] 
Hnátek, Milan. 2015. Entrepreneurial Thinking as a Key Factor of Family Business Success. Procedia-Social and Behavioral Sciences 181: 342-48. [CrossRef]

Hornsby, Jeffrey S., Donald F. Kuratko, Daniel T. Holt, and William J. Wales. 2013. Assessing a Measurement of Organizational Preparedness for Corporate Entrepreneurship. Journal of Product Innovation Management 30: 937-55. [CrossRef]

Hornsby, Jeffrey S., Donald F. Kuratko, Dean A. Shepherd, and Jennifer P. Bott. 2009. Managers' Corporate Entrepreneurial Actions: Examining Perception and Position. Journal of Business Venturing 24: 236-47. [CrossRef]

Hosseini, Mojtaba, Hossein Dadfar, and Staffan Brege. 2018. Firm-Level Entrepreneurship and International Performance: A Simultaneous Examination of Orientation and Action. Journal of International Entrepreneurship 16: 338-68. [CrossRef]

Hughes, Mathew, and Michael Mustafa. 2017. Antecedents of Corporate Entrepreneurship in SMEs: Evidence from an Emerging Economy. Journal of Small Business Management 55: 115-40. [CrossRef]

Jensen, Michael C., and William H. Meckling. 1976. Theory of the Firm: Managerial Behavior, Agency Costs and Ownership Structure I. Introduction and Summary in this Paper WC Draw on Recent Progress in the Theory of (1) Property Rights, Firm. In Addition to Tying Together Elements of the Theory of E. Journal of Financial Economics 3: 305-60. [CrossRef]

Jongwe, Antony I., Peter W. Moroz, Moses Gordon, and Robert B. Anderson. 2020. Strategic Alliances in Firm-Centric and Collective Contexts: Implications for Indigenous Entrepreneurship. Economies 8: 31. [CrossRef]

Keupp, Marcus Matthias, Maximilian Palmié, and Oliver Gassmann. 2012. The Strategic Management of Innovation: A Systematic Review and Paths for Future Research. International Journal of Management Reviews 14: 367-90. [CrossRef]

Kiwia, Rose Haynes, Kenneth M. K. Bengesi, and Daniel W. Ndyetabula. 2020. Succession Planning and Performance of Family-Owned Small and Medium Enterprises in Arusha City-Tanzania. Journal of Family Business Management 10: 213-30. [CrossRef]

Kotlar, Josip, and Philipp Sieger. 2019. Bounded rationality and bounded reliability: A study of nonfamily managers' entrepreneurial behavior in family firms. Entrepreneurship: Theory and Practice 43: 251-73. [CrossRef]

Kuye, O. L., B. E. A. Oghojafor, and A. A. Sulaimon. 2012. Planning Flexibility and Corporate Entrepreneurship in the Manufacturing Sector in Nigeria. International Journal of Business Excellence 5: 323-37. [CrossRef]

Leal-Rodríguez, Antonio L., Gema Albort-Morant, and Silvia Martelo-Landroguez. 2017. Links between Entrepreneurial Culture, Innovation, and Performance: The Moderating Role of Family Firms. International Entrepreneurship and Management Journal 13: 819-35. [CrossRef]

Lee, Kyootai, Marianna Makri, and Terri Scandura. 2019. The Effect of Psychological Ownership on Corporate Entrepreneurship: Comparisons Between Family and Nonfamily Top Management Team Members. Family Business Review 32: 10-30. [CrossRef]

Lewandowska, Anna. 2021. Interactions between Investments in Innovation and SME Competitiveness in the Peripheral Regions. Journal of International Studies 14: 285-307. [CrossRef]

Ling, Yan, Zeki Simsek, Michael H. Lubatkin, and John F. Veiga. 2008. Transformational Leadership's Role in Promoting Corporate Entrepreneurship: Examining the Ceo-Tmt Interface. Academy of Management Journal 51: 557-76. [CrossRef]

Liu, Gordon, Ke Rong, and Wai Wai Ko. 2020. Promoting Employee Entrepreneurial Attitudes: An Investigation of Chinese State-Owned Enterprises. International Journal of Human Resource Management 31: 2695-713. [CrossRef]

Lumpkin, G. Tom, and Gregory G. Dess. 1996. Clarifying the Entrepreneurial Orientation Construct and Linking It to Performance. Academy of Management Review 21: 135-72. [CrossRef]

Marchisio, Gaia, Pietro Mazzola, Salvatore Sciascia, Morgan Miles, and J. Astrachan. 2010. Corporate venturing in family business: The effects on the family and its members. Entrepreneurship and Regional Development 22: 349-77. [CrossRef]

Martín-Rojas, Rodrigo, Virginia Fernández-Pérez, and Encarnación García-Sánchez. 2017. Encouraging Organizational Performance through the Influence of Technological Distinctive Competencies on Components of Corporate Entrepreneurship. International Entrepreneurship and Management Journal 13: 397-426. [CrossRef]

Massaro, Maurizio, John Dumay, and Andrea Garlatti. 2015. Public sector knowledge management: A structured literature review. Journal of Knowledge Management 19: 530-58. [CrossRef]

Massaro, Maurizio, John Dumay, and James Guthrie. 2016. On the Shoulders of Giants: Undertaking a Structured Literature Review in Accounting. Ccounting, Auditing \& Accountability Journal 29: 767-801.

Mishra, Deepa, Angappa Gunasekaran, Thanos Papadopoulos, and Benjamin Hazen. 2017. Green Supply Chain Performance Measures: A Review and Bibliometric Analysis. Sustainable Production and Consumption 10: 85-99. [CrossRef]

Mustafa, Michael. 2015. Providing Organisational Support for Corporate Entrepreneurship: Evidence from a Malaysian Family Firm. International Journal of Entrepreneurship and Small Business 25: 414-41. [CrossRef]

Mustafa, Michael, John J. Richards, and Hazel Melanie Ramos. 2013. High Performance Human Resource Practices and Corporate Entrepreneurship: The Mediating Effect of Middle Managers Knowledge Collecting and Donating Behaviour. Asian Academy of Management Journal 18: 17-36.

Nabeel-Rehman, Rana, and Mohammad Nazri. 2019. Information technology capabilities and SMES performance: An understanding of a multimediation model for the manufacturing sector. Interdisciplinary Journal of Information, Knowledge, and Management 14: 253-76. [CrossRef]

Nadkarni, Swen, and Reinhard Prügl. 2021. Digital transformation: A review, synthesis and opportunities for future research. Management Review Quarterly 71: 233-341. [CrossRef] 
Najmulmunir, Nandang. 2020. Does reward enforcement and organization boundaries lead to sustainable supply chain performance in Indonesian SMEs? A moderating role of work discretion [Export Date: 13 July 2021]. International Journal of Supply Chain Management 9: 129-36.

Naldi, Lucia, Leona Achtenhagen, and Per Davidsson. 2015. International Corporate Entrepreneurship among SMEs: A Test of Stevenson's Notion of Entrepreneurial Management. Journal of Small Business Management 53: 780-800. [CrossRef]

Ndemezo, Etienne, and Charles Kayitana. 2018. Corporate Governance, Corporate Entrepreneurship and Firm Performance: Evidence from the Rwandese Manufacturing Industry. Indian Journal of Corporate Governance 11: 103-21. [CrossRef]

Noerhartati, E., Y. Soesatyo, Cholik T. Mutohir Moedjito, and Amrozi Khamidi. 2020. Determinants of sustainable supply chain performance: The role of corporate entrepreneurship in indecision textile companies. International Journal of Supply Chain Management 9: 106-12.

Poza, Ernesto J., and Mary S. Daugherty. 2014. Family Business. Cincinnati: South-Western Pub.

Raitis, Johanna, Innan Sasaki, and Josip Kotlar. 2021. System-Spanning Values Work and Entrepreneurial Growth in Family Firms. Journal of Management Studies 58: 104-34. [CrossRef]

Rehman, Nabeel, Sadaf Razaq, Ammara Farooq, Nayab Mufti Zohaib, and Mohammad Nazri. 2020. Information Technology and Firm Performance: Mediation Role of Absorptive Capacity and Corporate Entrepreneurship in Manufacturing SMEs. Technology Analysis and Strategic Management 32: 1049-65. [CrossRef]

Ripollés-Meliá, María, Martina Menguzzato-Boulard, and Luz Sánchez-Peinado. 2007. Entrepreneurial Orientation and International Commitment. Journal of International Entrepreneurship 5: 65-83. [CrossRef]

Riviezzo, Angelo, and Antonella Garofano. 2018. Accessing External Networks: The Role of Firm's Resources and Entrepreneurial Orientation. International Journal of Entrepreneurship and Small Business 34: 1-19. [CrossRef]

Romero-Martínez, Ana M., Zulima Fernández-Rodríguez, and Elena Vázquez-Inchausti. 2010. Exploring Corporate Entrepreneurship in Privatized Firms. Journal of World Business 45: 2-8. [CrossRef]

Roux, Ingrid, and Kenneth Bengesi. 2014. Dimensions of Entrepreneurial Orientation and Small and Medium Enterprise Performance in Emerging Economies. Development Southern Africa 31: 606-24. [CrossRef]

Sakhdari, Kamal, Henri Burgers, Jahangir Yadollahi Farsi, and Sasan Rostamnezhad. 2020. Shaping the Organisational Context for Corporate Entrepreneurship and Performance in Iran: The Interplay between Social Context and Performance Management. International Journal of Human Resource Management 31: 1020-46. [CrossRef]

Saleem, Irfan, Irfan Siddique, and Aqeel Ahmed. 2020. An Extension of the Socioemotional Wealth Perspective: Insights from an Asian Sample. Journal of Family Business Management 10: 293-312. [CrossRef]

Schindehutte, Minet, Michael H. Morris, and Donald F. Kuratko. 2018. Unpacking Corporate Entrepreneurship: A Critique and Extension. Advances in the Study of Entrepreneurship, Innovation, and Economic Growth 28: 11-35. [CrossRef]

Schmelter, Ralf, René Mauer, Andreas Engelen, and Malte Brettel. 2010. Conjuring the Entrepreneurial Spirit in Small and MediumSized Enterprises: The Influence of Management on Corporate Entrepreneurship. International Journal of Entrepreneurial Venturing 2: 159-84. [CrossRef]

Secundo, Giustina, Pasquale Del Vecchio, and Gioconda Mele. 2021. Social Media for Entrepreneurship: Myth or Reality? A Structured Literature Review and a Future Research Agenda. International Journal of Entrepreneurial Behaviour and Research 27: 149-77. [CrossRef]

Secundo, Giustina, Valentina Ndou, Pasquale Del Vecchio, and Gianluigi De Pascale. 2019. Knowledge Management in Entrepreneurial Universities: A Structured Literature Review and Avenue for Future Research Agenda. Management Decision 57: $3226-57$. [CrossRef]

Soares, Glauciana Gomes, Vitor Lélio da Silva Braga, Carla Susana da Encarnação Marques, and Vanessa Ratten. 2021. Corporate Entrepreneurship Education's Impact on Family Business Sustainability: A Case Study in Brazil. International Journal of Management Education 19: 100424. [CrossRef]

Soleimani, Maryam, and Ali Shahnazari. 2013. Studying Effective Factors on Corporate Entrepreneurship: Representing a Model. Research Journal of Applied Sciences, Engineering and Technology 5: 1309-16. [CrossRef]

Soliman, Amal Farouk. 2019. A Proposed Model for the Effect of Entrepreneurship on Total Quality Management Implementation: An Applied Study on Dairy and Juice Manufacturing Companies in Egypt. International Journal of Six Sigma and Competitive Advantage 11: 179-203. [CrossRef]

Sriviboon, Chutikarn. 2020. Impact of selected factors on job performance of employees in it sector: A case study of Indonesia. Journal of Security and Sustainability Issues 9: 28-41. [CrossRef]

Stopford, John M., and Charles W. F. Baden-Fuller. 1994. Creating Corporate Entrepreneurship. Strategic Management Journal 15: 521-36. [CrossRef]

Thomas, Nobin, Angela Randolph, and Alejandra Marin. 2020. A Network View of Entrepreneurial Cognition in Corporate Entrepreneurship Contexts: A Socially Situated Approach. Management Decision 58: 1331-54. [CrossRef]

Toledano, Nuria, David Urbano, and Marc Bernadich. 2010. Networks and corporate entrepreneurship: A comparative case study on family business in Catalonia. Journal of Organizational Change Management 23: 396-412. [CrossRef]

Tranfield, David, David Denyer, and Palminder Smart. 2003. Towards a Methodology for Developing Evidence-Informed Management Knowledge by Means of Systematic Review. British Journal of Management 14: 207-22. [CrossRef] 
Van Wyk, Rene, and Mandla Adonisi. 2012. Antecedents of Corporate Entrepreneurship. South African Journal of Business Management 43: 65-78. [CrossRef]

Mehta, Mita. 2020. Effect of Leadership Styles on Corporate Entrepreneurship: A Critical Literature Review. Organization Development Journal 38: 65-74.

Villalonga, Belen, and Raphael Amit. 2006. How Do Family Ownership, Control and Management Affect Firm Value? Journal of Financial Economics 80: 385-417. [CrossRef]

Weiss, Lysander, and Dominik K. Kanbach. 2021. Toward an Integrated Framework of Corporate Venturing for Organizational Ambidexterity as a Dynamic Capability. Management Review Quarterly. [CrossRef]

Zahra, Shaker A. 1991. Predictors and Financial Outcomes of Corporate Entrepreneurship: An Exploratory Study. Journal of Business Venturing 6: 259-85. [CrossRef]

Ziyae, Babak, and Hossein Sadeghi. 2020. Exploring the relationship between corporate entrepreneurship and firm performance: The mediating effect of strategic entrepreneurship. Baltic Journal of Management 16: 113-33. [CrossRef] 